\title{
MA により作製したアモルファス Se-Te の中性子回折
}

\author{
伊藤 恵司的 1 , 三沢 正勝的 2 , 福永 俊晴的 1 \\ 41 京都大学原子炬実験所, $\bar{T} 590-0494$ 大阪府泉南郡熊取町野田. \\ \2 新潟大学理学部, $=950-2181$ 新潟市五十嵐 2 の町 8050.
}

\section{Neutron Diffraction of Amorphous Se-Te Prepared by MA}

\author{
Keiji Itoh ${ }^{\not 1}$, Masakatsu Misawa ${ }^{\text {क } 2}$ and Toshiharu Fukunaga ${ }^{\text {का }}$ \\ \$1 Research Reactor Institute, Kyoto University, Kumatori-cho, Sennan-gun, Osaka 590-0494. \\ के ${ }^{2}$ Depertment of Chemistry, Faculty of Science, Niigata University, 8050 Ikarashi 2-no-cho, Niigata 950-2181.
}

Received April 11, 2001

\section{SYNOPSIS}

Amorphous $\mathrm{Se}_{100-x} \mathrm{Te}_{x}$ powders ( $x=0,5,10,15$ and 20 ) have been produced by mechanical alloying (MA). The time-of-flight neutron scattering measurement was employed in order to elucidate the short range structures for these powders. Well-resolved first peak in radial distribution functions can be decomposed into two Gaussian peaks, which correspond to the Se-Se and Se-Te correlations. The coordination number teaches us that amorphous Se has a lot of dangling bonds due to broken of Se-Se bond by milling. However, the compositional changes of the coordination numbers of Se-Se and Se-Te pairs for Se-Te powders imply that $\mathrm{Te}$ atoms are bonded to the edge of Se chain molecules and the twofold chain structure is built up with increasing Te content.

KEY WORDS

mechanical alloying, neutron diffraction, dangling bond, short range structures

\section{1 緒 言}

アモルファス合金は，液相や気相から高い急冷速度で冷却 して得られるばかりではなく,メカニカルミリング法(MM), もしくはメカニカルアロイング法(MA)により，固相に扔いて 作製することができる ${ }^{1.2)}$. 特に MM及び MA で作製されたカ ルコゲン系アモルファス合金については，その短距離構造が 急冷法によるそれとは異なることが最近の中性子回折を用いた 構造解析によって見出されている3-5). 結晶 Se 及び Te は 3 回 対称の螺旋鎖状分子からなる。鎖状分子内の結合は 2 配位の 共有結合で，鎖間はvan der Waals 力による結合である. 最近， 結晶Se粉末をミリングすると 25 時間程度でBraggピークが消 失し，アモルファス化することが報告されている，また，最 近接配位数が通常の 2 個よりも小さくなることから，ミリン グにより Se-Se 結合が切断され，ダングリングボンドが多く 存在することが明らかになっている゙。

本研究ではMAにより Se-Te系アモルファス合金を作製し， SeにTeを添加することによる短距離構造の変化を, パルス中 性子回折の特徵を利用して観察した。

\section{2 試料及び実験方法}

\section{1 試料作製}

$\mathrm{Se}$ 粉末 $(99.999 \%)$ 及び Te 粉末 $(99.999 \%)$ を SUS304 製のミり ング容器 $(80 \mathrm{cc})$ にボール $(10 \mathrm{~mm} \phi) 30$ 個とともに入れ, 試料 の酸化を防ぐために容器内をアルゴン置換した。ミリングは Firtsch社製の遊星型ボールミル装置(P-5)を用い, 30 分運転後 10 分停止というモードで行った，150時間のミリングにより， $\mathrm{Se}, \mathrm{Se}_{95} \mathrm{Te}_{5}, \mathrm{Se}_{90} \mathrm{Te}_{10}, \mathrm{Se}_{85} \mathrm{Te}_{15}, \mathrm{Se}_{80} \mathrm{Te}_{20}$ の5 組成の試料を作製した。 ミリング過程の試料を Mo-K $\alpha$ 線を用いたX線回折により，適 宜観察しアモルファス化の確認を行った。

\section{2 中性子回折実験}

中性子回折実験は高エネルギー加速器研究機構・物質構造 科学研究所に設置されているHIT-II回折装置を用いて行われ た. 得られた散乱強度のデータについて吸収や多重散乱等の 補正及び規格化を行うことにより 0.77 ，構造因子 $S(Q)$ を得た。 実空間の情報である動径分布関数 $R D F(r)$ は，(1)式により $S(Q)$ をフーリエ変換することにより得た。

$$
R D F(r)=4 \pi r^{2} \rho+\frac{2 r}{\pi} \int_{0}^{\infty} Q(S(Q)-1) \sin Q r d Q
$$


ここで $\rho$ は数密度である。数密度はトルエンを用いたアルキ メデス法により測定した．(1)式の積分は $Q=$ ままであるが， 実際の測定では有限の $Q$ の值までしか測定できない.カルコ ゲン系のような共有結合性のアモルファス物質は, 結合距離 の摇らぎが小さく $S(Q)$ の振幅は高い $Q$ 領域まで持続する。そ のため, フーリ工変換の打切り効果がRDF(r)のピーク分解能 に大きく影響する. 近接する2種類以上の結合距離の分離や， 短距離構造についての詳細な議論のためには，高い $Q$ 領域ま での $S(Q)$ の測定が必要である. 本研究では, パルス中性子の 特徴を生かして $2-500 \mathrm{~nm}^{-1}$ における広い $Q$ 領域の $S(Q)$ を得, これをフーリエ変換することにより，高分解能のRDF( $r)$ を得 た.

\section{3 結 果}

$\mathrm{MA}$ によるアモルファス $\mathrm{Se}_{100-x} \mathrm{Te}_{x}$ 合金の作製に成功したの は $x=0$ ２0の絽成範囲である。ここで， $x=20$ 組成に注目し てミリングによるアモルファス化過程を眺めてみる. Fig.1は $x=20$ 組成における構造因子 $S(Q)$ の MA 時間依存性を示した ものである。 0 時間の MA では Se及び Te の Bragg ピークが観 測されているが，これらのと゚ークは MA 時間とともに小さく なり，100時間のMAで $S(Q)$ はアモルファス特有のハローパ ターンになっている.このとき数密度は Fig.2に示すように， ミリング初期に扔いて急激に減少しているが，50hを超えた あたりでほほ一定の值になる. Fig.1のS $(Q)$ をフーリ工変換して 得られた $R D F(r)$ を Fig.3に示す。時間の MAにおける $0.237 \mathrm{~nm}$

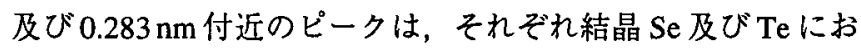

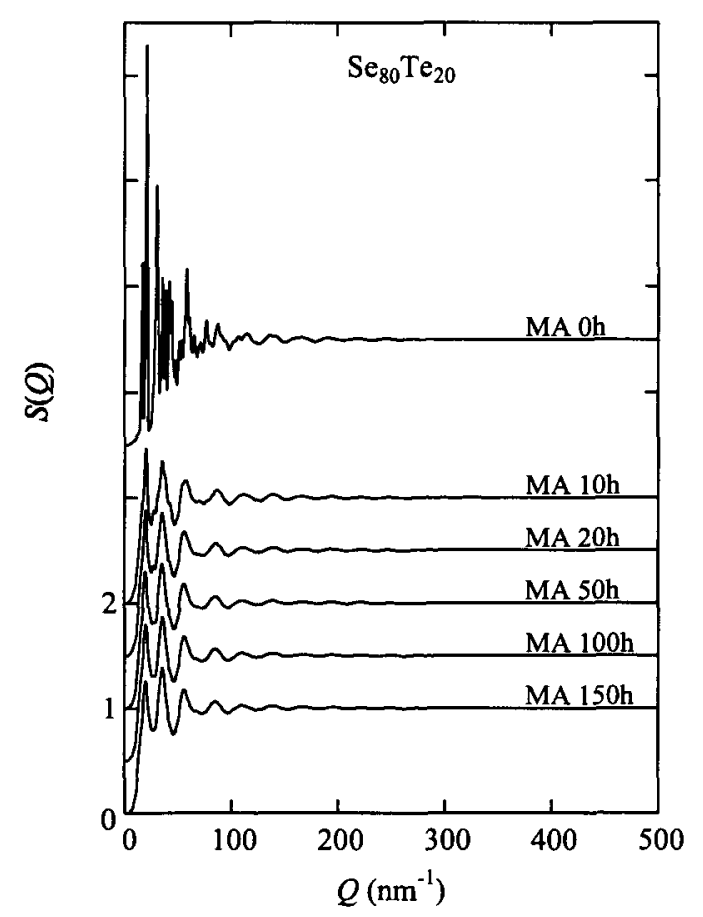

Fig.1 Structure factors, $S(Q)$, for $\mathrm{Se}_{80} \mathrm{Te}_{20}$ powder as a function of milling time.
ける Se-Se及び Te-Te 相関に相当する. Te-Te 相関のピークは ミリングとともに小さくなり，150時間のMAで完全に消失す る。一方, $0.255 \mathrm{~nm}$ 付近に新たなピークが発達しており，MA により結合の切断のみならず新たな結合が形成されているこ とを示している。

Fig.4にMAで作製されたアモルファスSe-Te合金の $S(Q)$ の 組成依存性を示す。振幅が Te濃度の増加とともにわずかに減 少していることを除けば, $S(Q)$ の形状はほとんど変化してい ない.また，Fig.5に示すように，数密度は単調な組成変化を する. Fig.4の $S(Q)$ をフーリエ変換して得られた $R D F(r)$ を Fig.6に示す. Se-Te系のような 2 元合金の場合, $R D F(r)$ は(2)式

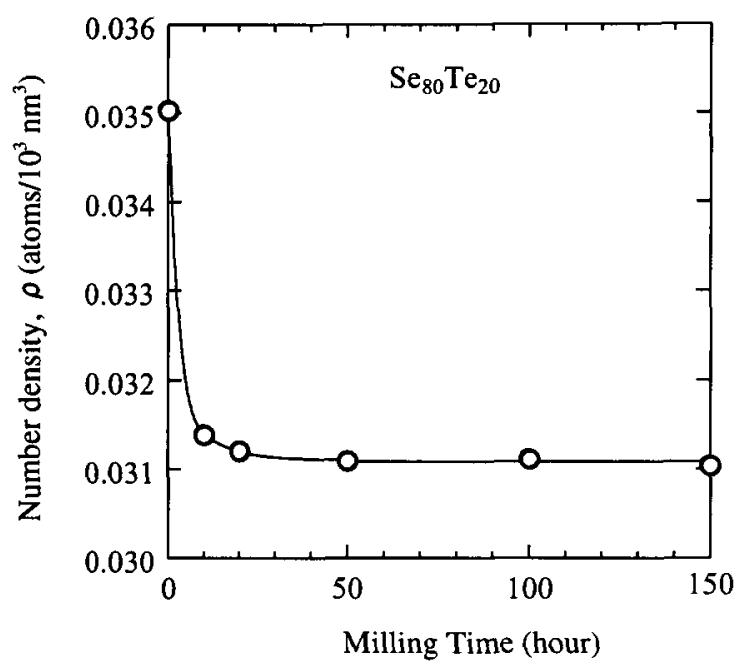

Fig.2 Number density for $\mathrm{Se}_{80} \mathrm{Te}_{20}$ powder as a function of milling time.

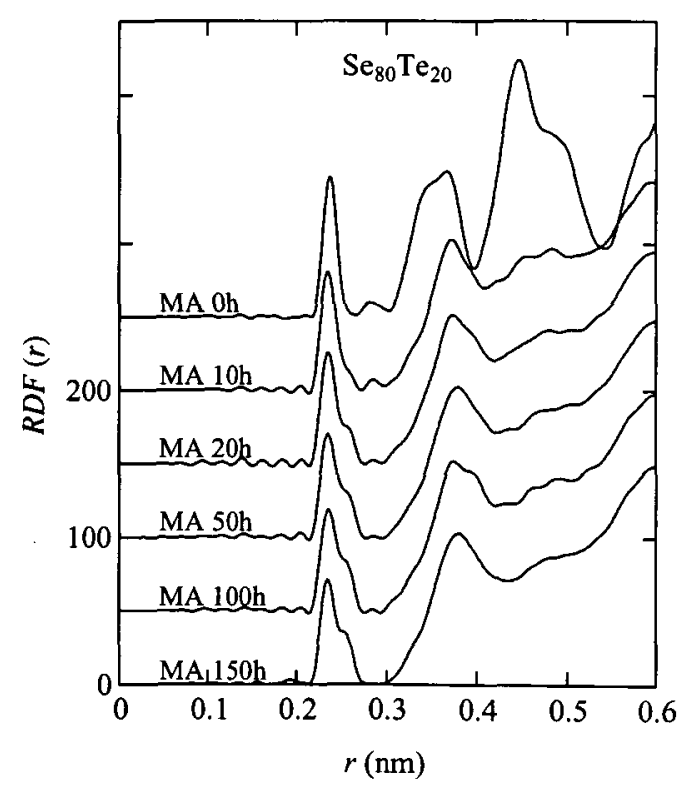

Fig.3 Radial distribution functions, $R D F(r)$, for $\mathrm{Se}_{80} \mathrm{Te}_{20}$ powder as a function of milling time. 
に示すように Se-Se, Se-Te 及び Te-Te 相関を表す部分動径分 布関数 $R D F_{\mathrm{i}-\mathrm{j}}(r)$ の重みつき和として表される ${ }^{8)}$.

$$
\begin{aligned}
& R D F(r)= \frac{1}{\langle b\rangle^{2}}\left\{c_{\mathrm{Se}}^{2} b_{\mathrm{Se}}^{2} R D F_{\mathrm{SeSe}}(r)\right. \\
&\left.+2 c_{\mathrm{Se}} c_{\mathrm{Te}} b_{\mathrm{Se}} b_{\mathrm{Te}} R D F_{\mathrm{SeTe}}(r)+c_{\mathrm{Te}}^{2} b_{\mathrm{Te}}^{2} R D F_{\mathrm{TeTe}}(r)\right\} \\
&\langle b\rangle=c_{\mathrm{Se}} b_{\mathrm{Se}}+c_{\mathrm{Te}} b_{\mathrm{Te}}
\end{aligned}
$$

ここで $c_{\mathrm{Se}}\left(c_{\mathrm{Te}}\right)$ 及び $b_{\mathrm{Se}}\left(b_{\mathrm{Te}}\right)$ は $\mathrm{Se}(\mathrm{Te})$ の濃度及び中性子の干涉 性散乱振幅である. Seに Teを添加することにより，RDF $(r)$ の $0.255 \mathrm{~nm}$ 付近に Se-Te 相関に相当するピークが出現しこ こ れは $\mathrm{Te}$ 濃度の増加とともに発達している。この Se-Te相関は

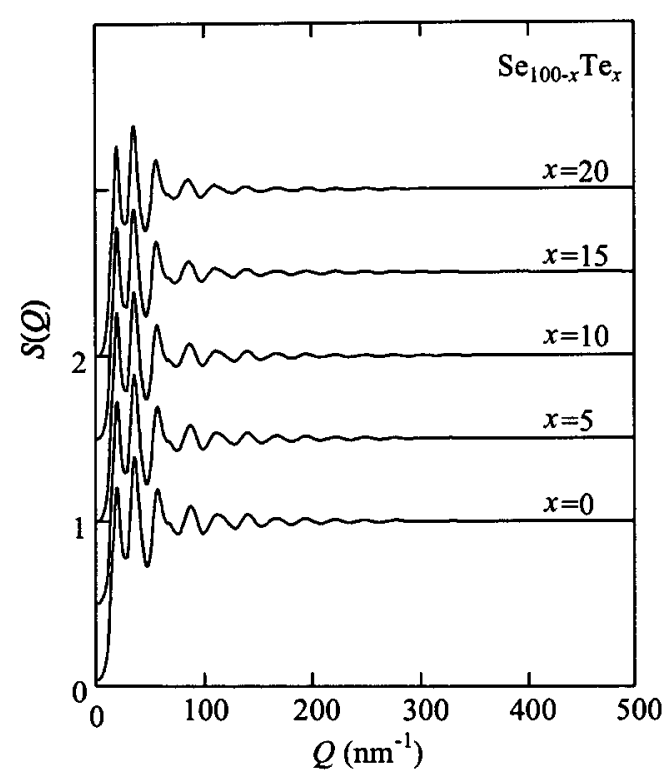

Fig.4 Concentration variation of the structure factors, $S(Q)$, for amorphous $\mathrm{Se}_{100-x} \mathrm{Te}_{x}(x=0,5,10,15$ and 20$)$ powders.

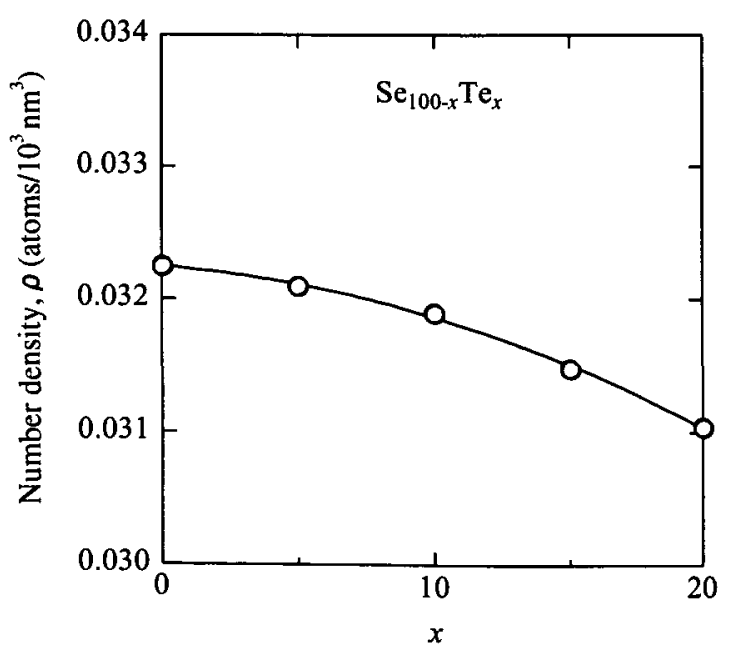

Fig.5 Concentration variation of the number density, $\rho$, for amorphous $\mathrm{Se}_{100-x} \mathrm{Te}_{x}$ powders.
Se-Se相関と近距離にあるた岁と゚ータが重なっているが,がウ ス関数フイッティングにより,2つのピークを容易に分離する ことができる. 分離された Se-Se及び Se-Te 相関はFig.6に破 線で示した.Fig.7はそれぞれのピーク面積から求めた最近接

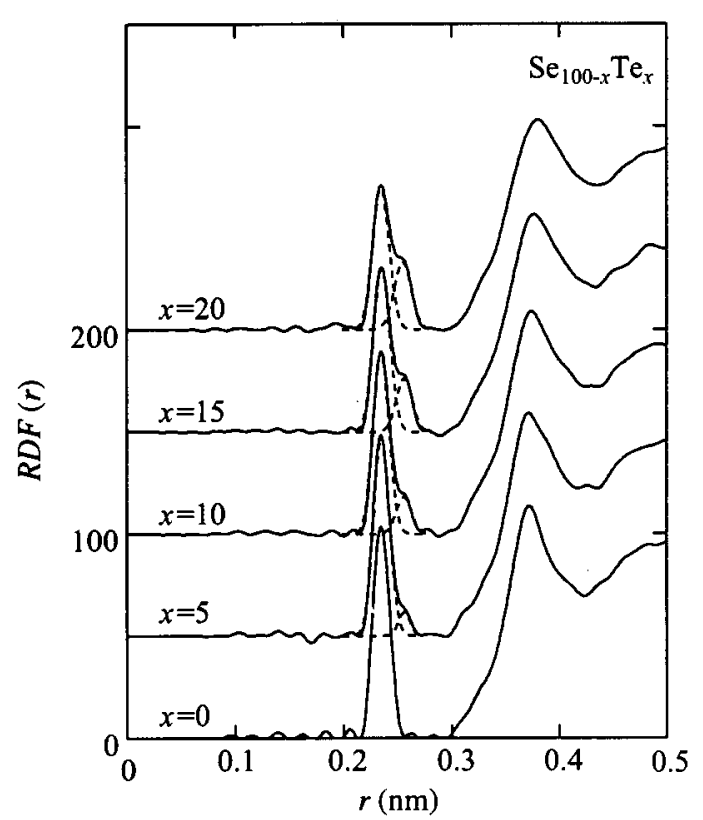

Fig.6 Concentration variation of the radial distribution functions, $R D F(r)$, for amorphous $\mathrm{Se}_{100-x} \mathrm{Te}_{x}(x=0,5,10,15$ and 20) powders. Broken curves are Gaussian functions corresponding to the $\mathrm{Se}-\mathrm{Se}$ and $\mathrm{Se}-\mathrm{Te}$ correlations.

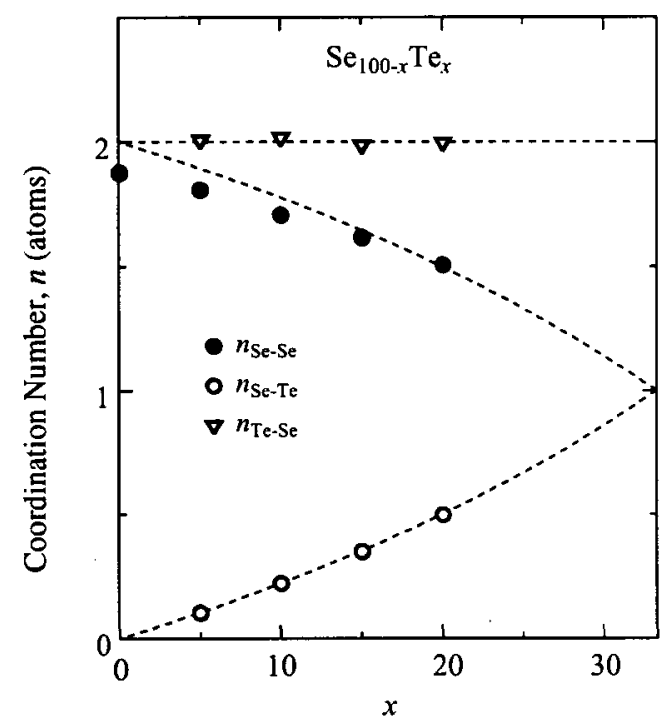

Fig.7 Concentration variation of nearest neighbor coordination numbers calculated from the area of Gaussian peaks in $R D F$ (r) for amorphous $\mathrm{Se}_{100-x} \mathrm{Te}_{x}(x=0,5,10,15$ and 20) powders. $n_{\mathrm{Se}-\mathrm{Se}}\left(n_{\mathrm{Se}-\mathrm{Te}}, n_{\mathrm{Te}-\mathrm{Se}}\right)$ means the coordination number of the nearest $\mathrm{Se}(\mathrm{Te}, \mathrm{Se})$ atoms around a $\mathrm{Se}(\mathrm{Se}, \mathrm{Te})$ atom and broken lines indicate the coordination number of Se-Se, Se-Te and Te-Se pares in case of twofold chain structure. 


\section{O Se OTe}

(a)

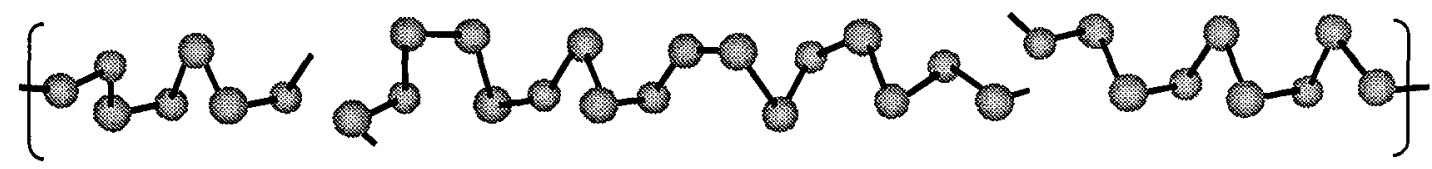

(b)

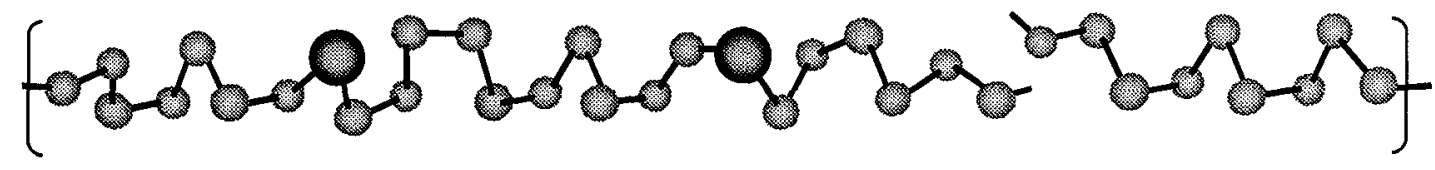

(c)

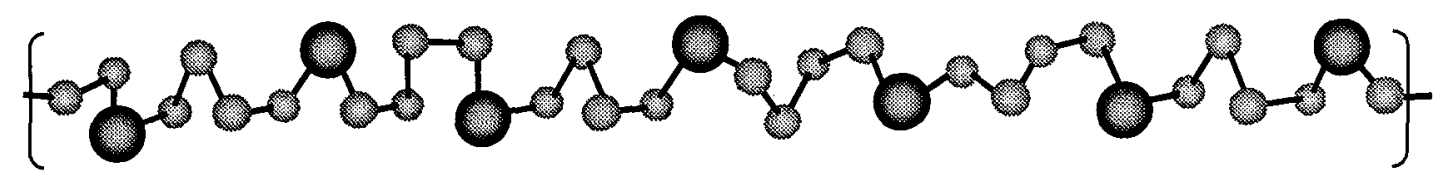

Fig.8 Schematic representation of short rang structure for amorphous $\mathrm{Se}_{100-x} \mathrm{Te}_{x}$ powders. (a) amorphous Se, (b) amorphous $\mathrm{Se}_{100-x} \mathrm{Te}_{x}(x: 0 \sim 20$ ), (c) amorphous $\mathrm{Se}_{80} \mathrm{Te}_{20}$.

配位数の組成依存性を示したものであり，破線は 2 配位鎖状 構造を形成しているときのそれぞれの配位数の值である. 前 述したようにアモルファス Seの最近接配位数は 1.88 個と 2 個 より小さく、これはダングリングボンドが多く存在している ことを示している，ところが，Teの増加とともに， Se周囲の $\mathrm{Se}$ の最近接配位数 $n_{\mathrm{se}-\mathrm{Se}}$ は 2 配位鎖状構造における值に近づい ている. また, $\mathrm{Te}$ 周囲の Se の最近接配位数 $n_{\mathrm{Te}-\mathrm{Se}}$ は全ての組 成で2個でありここれは $\mathrm{Te}$ 原子が $\mathrm{Se}$ チェーン内に位置してい ることを示している．以上のことから，Fig.8(a)-(c)に示した ような構造変化が推察される.ミリングによりアモルファス 化したSeは, Se-Se 結合が切断されダングリングボンドの多 い構造を有する(Fig.8 (a)).これに Te を添加すると, $\mathrm{Se}$ のダ ングリングボンドと Te が結合し (Fig.8(b)), Te 濃度の増加に 伴いチェーンが長くなっていく. $\mathrm{Se}_{80} \mathrm{Te}_{20}$ 組成に至っては2配 位鎖状構造が形成される (Fig.8(c)).

\section{4 まとめ}

メカニカルアロイングにより作製された $\mathrm{Se}-\mathrm{Te}$ 系アモル ファス合金について，パルス中性子回折実験によって短距離 構造を観察した。得られた最近接配位数の值から、アモル ファスSeではミリングにより Se-Se結合が切断されダングリ ングボンドが多く存在しているが, $\mathrm{Te}$ の増加とともに $\mathrm{Se}$ のダ ングリングボンドと Teが結合し2配位鎖状構造が形成される ことが明らかとなった。

\section{文献}

1) C.C.Koch, O.B.Calvin, C.G.Macklamey and J.O.Scarbrough: "Preparation of amorphous $\mathrm{Ni}_{60} \mathrm{Nb}_{40}$ by mechanical alloying", Appl. Phys. Lett., 43(1983)1017-1019.

2) R.B.Schwarz and C.C.Koch: "Formation of amorphous alloys by the mechanical alloying of crystalline powders of pure metals and powders of intermetallics", Appl. Phys. Lett., 49(1986)146-148.

3) T.Fukunaga, M.Utsumi, H.Akatsuka, M.Misawa and U.Mizutani: "Structure of amorphous Se prepared by milling", J. Non-Cryst. Solids, 205-207(1996)531-535.

4) T.Fukunaga, S.Kajikawa Y.Hokari, Mizutani: "The structure of amorphous Se-S prepared by mechanical alloying", J. Non-Cryst. Solids, 232-234(1998)465-469.

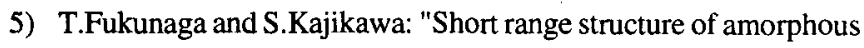
$\mathrm{Se}_{100-\mathrm{x}} \mathrm{As} \mathrm{s}_{\mathrm{x}}$ prepared by mechanical alloying", J. Non-Cryst. Solids, 250-252(1999)384-388.

6) H.H.Paalman and C.J.Pings: "Numerical evaluation of X-ray absorption factors for cylindrical samples and annular sample cells", J. Appl. Phys., 33(1965)2635-2639.

7) I.A.Blech and B.L.Averbach: "Multiple scattering of neutrons in vanadium and copper", Phys. Rev., 137(1965)1113-1116.

8) T.E.Faber and J.M.Ziman: "A theory of the electrical properties of liquid metals III. The resistivity of binary alloys", Philos. Mag., 11(1965)153-173. 